\title{
高分子材料の最近の進歩
}

\author{
2. ポリマーネットワーク系
}

粷 谷 信 三* 浦 山 健 治** 瀧 川 敏 算 ${ }^{* * *}$

\section{Recent Progress in Polymer Materials}

\section{II : Polymer Network Systems}

by

\author{
Shinzo KohJiYA ${ }^{*}$, Kenji URaYama ${ }^{* *}$ and Toshikazu TaKIgaWA ${ }^{* * *}$
}

Key words : Polymer network, Polymer gel, Rubber elasticity, Swelling, Thermoplastic elastomer

\section{1 はじめに}

ポリマーネットワークは, 高分子鎖の 3 次元網目構造 体であり, その網目状の構造に起因してゴム弾性, 膨潤 特性などのユニークな物性を発現する。これらの物性の 特異性を生かしてポリマーネットワーク系材料は古くか ら工業的に応用され，現在に至るまで高分子材料の中で も重要かつ独自の位置を占め続けている，例を挙げれば， 古くから自動車タイヤなどに用いられ，兵庫県南部地震 によって一般にも知られるようになった免震ゴムに代表 される架橋ゴムや，最近の高吸水性材料なごに使われて いる高分子ゲルもポリマーネットワークに属する.

ポリマーネットワーク系を材料として扱う場合のキー ワードとしては，無数の高分子鎖が橋架け（架橋）され た $\lceil 3$ 次元網目構造」, 小さな力で可逆的な大変形が可能 な「ゴム弾性」, 外部溶媒を取り込んで大きな体積変化を 示す「膨潤特性」が挙げられる.「3 次元網目構造」はポ リマーネットワーク系の必須条件であり, 何らかの架橋 構造を系へ導入することが必要と考えられてきた，最近， 化学架橋構造の導入を要しないゴム弾性体（エラストマ 一)「熱可塑性エラストマー (TPE)」が注目を集めてい る. TPE は後述するように化学架橋を要しないために加 工成形性に極めて優れ工業材料としての期待が増々大き くなっている. 本稿の第 2 章ではこの TPEの概念抢よび 物性について紹介する。「ゴム弾性」および「膨潤特性」 はポリマーネットワーク独自の物性であり, ポリマーネ ットワークが魅力的な材料たる由縁でもある。本稿の 3 章では, ゴム弾性の最近のトピックスとして, 既存の エラストマーの破壊伸びをはるかに超える高伸長性を発 現するシリコーンゲルを紹介する．また， 4 章では膨潤 特性に関連した新しい話題として, 変形（応力やひずみ） 下および溶媒流れ場中に置かれたゲルの膨潤および力学
緩和の研究について述べる. 最近, ゲルのアクチュエー ター (一種のエネルギー変換システム) への応用が検討 されているが, この場合ゲルは溶媒中で駆動されるため, この問題は学問的のみならず応用面でも重要である.

\section{2 熱可塑性エラストマー}

\section{$2 \cdot 1$ 熱可塑性エラストマーの分子設計}

熱可塑性エラストマー (TPE) とは「高温で可塑化さ れてプラスチックスと同様に成形が可能で，常温あるい は使用温度ではゴム弾性体（エラストマー）の性質を示 す高分子材料」と定義される. TPE を分子設計するうえ でのポイントは, 高温で可塑化されなければならないの で加硫ゴムのような共有結合による化学架橋構造を有し てはならないことと, 常温付近でエラストマーになるた めには架橋に代る何らかの仕掛を導入する必要があるこ と，である。これらの条件を満たすような構造の分子設 計は, 結論的に次のようになる. すなわち, TPEの分子 はエントロピー弾性を発現させるためのゴム成分（ソフ

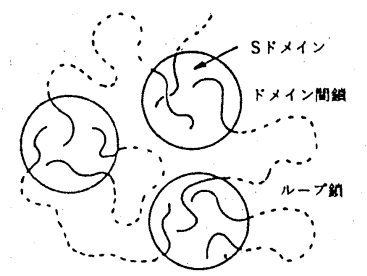

(a)

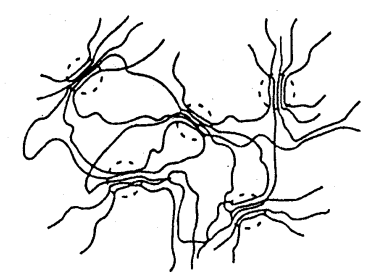

(b)
図 1 熱可塑性エラストマー（ブロックコポリマー） に打けるミクロ相分離構造の模式図

(a) ABA 型ブロックコポリマー：SBS を例とし て示し, 実線はポリスチレン(PS), 破線はポリブ タジエン $(\mathrm{PB})$

(b) マルティブロックコポリマー：破線で示し た円はハードセグメントドメイン 
トセグメント）と，凝集してドメインと呼ばれる領域を 形成しネットワーク構造の結節点となる拘束成分（ハー ドセグメント；架橋点に代る仕掛）を持たなければなら ない. 両成分はドメイン形成のためには非相溶でありな がらも，ネットワーク形成のためには少なくともマクロ に相分離してはならないことが必要とされる. 従って, TPE としてブロックコポリマーあるいはグラフトコポリ マーが, 分子設計上最も単純な対象となる.

代表的な TPE として, トリブロックコポリマーである ポリスチレンーポリブタジエンーポリスチレン (SBS) お。 よびポリウレタン (PU) のようなマルチブロックコポリ マーのミクロ相分離構造を図 1 に模式的に示す. ${ }^{2)}$, 3) ここ でドメインは可視光の波長 $(380 \sim 770 \mathrm{~nm})$ より小さく, コポリマー両成分の相分離はポリマー鎖の次元であり, ミクロ相分離と呼ばれる由縁になっている。このように， TPE の分子設計としては, ソフトセグメントにはゴムが, ハードセグメントにはプラスチックが用いられ，ドメイ ンはプラスチックの性質によりガラスあるいは結晶が担 う. ブロックコポリマーのミクロ相分離構造は, 高分子 集合体や超分子構造, ナノ構造の先駆けとなったもので, 現在でも高分子科学の中心的課題として活発な研究が行 われている.

\section{$2 \cdot 2$ TPE の特長}

(1) 加硫の不要性 TPE において化学架橋構造の導 入が不要であることは, 成形加工の技術の点で大きな意 義を有している，すなわち，TPE の成形加工では架橋あ るいは加硫の工程が不必要であるため, 架橋ゴムと比較 すると，加硫に必要な配合剤が必要でないことはもちろ ん, 加工プロセスが著しく簡素化された. 化学反応であ るが故に成形加工プロセスの中で特別の重要性を有して いた加硫工程が不要になったために, TPE は熱可塑性プ ラスチック用の機械による加工, 中でも射出成形が極め て容易になった。

(2) ミクロ相分離構造に起因する自己補強効果 TPE が補強充てん淯なしでも, ミクロ相分離構造に起因する 自己補強効果のために一定の弾性率や強度を示す。この ため, TPEでは合成ゴムにとって必須であったカーボン ブラックなどの補強性充てん郕の配合が不要となった. このことは加工プロセスを簡素化しただけでなく, カー ボンが不要となったことから，白色穴の他の色物の作製 を可能にした.

（3）ゴムとプラスチックの中間の物性 2) の作用の結 果として, TPE は一般にプラスチックとゴムの間にある 弾性率や強度のギャップを埋める材料になっている. 例 えば，両者の中間的な力学特性を有する数少ない材料に 皮革があるが，人工皮革として成功したのは TPEである ポリウレタンを用いたものであった。 また，従来プラス チック（例えばポリ塩化ビニル）への大量の可塑郕ある いは軟化剤の配合によって対処されてきた分野でも，有 毒な可塑剤の溶出や移行などのトラブルを解消する材料
として TPE は極めて有効である。これら 3 つの特長は TPE の市場に打ける伸びを支える基盤になっている.

（4）リサイクル性 TPE は共有結合による架橋構造 をもたないので，成形品，バリ，スクラップなどの再利 用が可能である。リサイクル可能というこの特長は，近 年の地球的環境の危機を解決するために有効な性質であ り, TPEの将来動向を考える上で重要な点であろう.

以上の上うな優れた特長の結果として, 現在かなり多 数の TPE が市場に現れ，生産量あるいは消費量も全体 として拡大の一途をたどっている.

\section{3「動的架橋」による TPE の新展開}

上述したように多様な可能性のある TPEであるが，勿 論いくつか弱点はあり, その最大の問題点は架橋ゴムに 比べて劣る耐熱性である．もともと成形加工上の理由で 熱可塑性を付与したのであるから，耐熱性の向上と成 形加工性の改善とは両立し得ないものといえる. 理論的 にはその通りであるが，現実には加工性を多少犠牲にし ても耐熱性を向上させようとする試みが盛んに行われて いる.

耐熱性向上を含めて TPE の高性能化に用いられる手 法は, (1)架橋, (2)ブレンド, ポリマーアロイ化, (3)フィ ラー, 短繊維充てん, およびこれら 3 つの手法の組み合 わせである. (1)と(2)を組み合わせて TPE の世界で新たな ブレークスルーを成し遂げたのが「動的架橋」である.1) 動的架橋とは，「溶融状態にある熱可塑性プラスチックに ゴムを混入し，架橋剂を加えて混練り条件下，ゴム成分 の架橋反応を行う技術」である. 図 2 に動的架橋体のモ ルフォロジーを示す. 架橋ゴムが分散相で樹脂成分がマ トリックス（連続相）になっており，熱可塑性である.

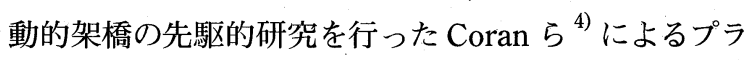
スチック成分にポリプロピレン (PP) を，ゴム成分に EPDM を用いた動的架橋体の研究例を紹介する。この複 合体のヤング率を, 組成に対してプロットすると図 3 の ようになる。実測のヤング率は, 広い組成範囲で加成性 を仮定して計算された值より大きく，ポリマーアロイに 分類できる複合体の生成を示している.

興味深いのは，動的架橋体が図 2 のように樹脂である PP がマトリックスであるのに, エラストマーになること である.この問いに対しては，現在 2 つの回答がある. 井上 ${ }^{5,6)}$ は 2 次元有限要素法による応力解析を行い,

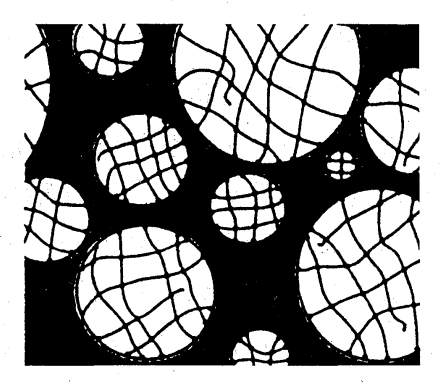

目 2 動的架橋体のモルフォロジー 


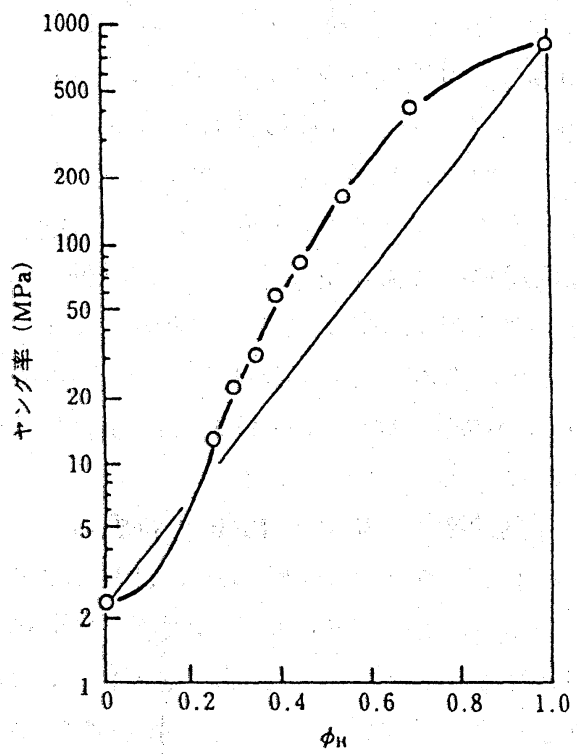

図 $3 \mathrm{EPDM} / \mathrm{PP}$ 動的架橋体のヤング率の組成依存性 $\phi_{H}$ はPPの体積分率

EPDM 粒子間の PP はかなりの大変形後も弾性を保って いて降伏していないことを示した. 川端ら ${ }^{7)}$ は連続相の 樹脂部分はバネとして挙動するゴム粒子がばらばらにな らぬように接着させる役割を担っているモデルを考案し た。このモデルは，ゴム粒子は巨視的変形よりも大きく 変形することを予測する。

\section{$2 \cdot 4$ TPE の今後の展望}

メタロセン触蝶系によるオレフィン重合に代表される 新しい合成法の進展により，様々なセグメントの組み合 わせが可能になり，新しいTPE の創製が今後も活発に行 われるであろう. また，TPE 岋熱可塑性であることから， 溶融混合によるブレンド法を用いることで様々な性質を 生み出せる. 特に, 動的架橋体で用いられたリアクティ ブプロセッシングの技術によってさらに新しい TPE が開 発されると思われる。

\section{3 超高伸長性エラストマー}

エラストマーの可逆的な高伸長性はゴム弾性の最も重 要な性質であり, 古くからゴム製品として工業的に利用 されるとともに，その分子諭的起源㹥多くの研究者の研 究対象となってきた。可逆的な高伸長性の本質は, 高分 子網目構造とそれを形成する網目鎖のエントロピー弾性 にある. 種々のゴム架橋体の破断伸び $\lambda_{\text {max }}$ (一軸伸長し たとき破断が起こる点での伸びひずみであり，ここでは 破断時の試料長と初期長の比として定義する）が報告さ

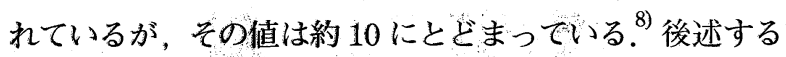
ように，エラストマーの $\lambda_{\text {max }}$ は網目構造のトポロジーと 密接に関連しており，バルク (無溶媒) 状態で架橋する 限り $\lambda_{\text {max }}$ は 10 程度の上限を持つことが説明される。最 近，我々は低濃度溶液中で作製したポリジメチルシロキ サン (PDMS) ゲルから溶媒を完全に除去 (脱膨潤) す ることによって得られる脱膨潤ゲルの $\lambda_{\text {max }}$ が 30 を超え る高伸長性を有することを示した，脱膨潤時のゲルの大
きな体積変化のために, 脱膨潤ゲルの網目鎖は高分子鎖 の自然状態とされる random-coil よりも密なコンフォメ ーション (super-coil) を形成するために, 脱膨潤ゲルは random-coil の網目鎖から成るバルク架橋ゲルとはかなり 異なった物性を示すことが以前から理論的に予測されて

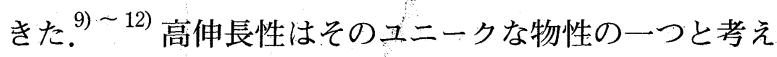
られる. 本稿では, 脱膨潤ゲルの高伸長性と特異な応力 の伸び依存性を紹介する。

\section{$3 \cdot 1$ 超高伸長性の理論的背景 $\left.{ }^{12)} \sim 16\right)$}

一般に材料の破壊現象は試料の欠陥, 傷などが主因と なって生じることが知られているが，ここでは問題を単 純化するために，ゲルの破断は網目鎖が伸長によって伸 び切ることによって起こり, 架橋点は外部変形に対し比 例変位（アフィン変形）すると仮定する。 また, 分子量 が均一な一次高分子鎖を末端架橋することによって得ら れるゲル, すなわち化学架橋点間の分子量が均一で一次 高分子鎖の分子量に等しいゲルを対象とする.

セグメント数 $N$ の一本鎖の $\lambda_{\text {max }}$ は, 鎖の未変形時の 両末端間距離 $\left(R_{0}=b N^{1 / 2}\right)$ を完全に伸び切った状態 $(R=b N)$ にするのに必要な伸びであり， $\lambda_{\max }=N^{1 / 2}$ である. ${ }^{17)} こ$ こで $N$ および $b$ は実在鎖を自由連結鎖に置き換えたとき のセグメントの数および長さである.

セグメント数 $N$ の高分子鎖を一次鎖として架橋体を作 製する時， $N$ が大きくなれば架橋前に一次鎖同士の絡み 合いが存在し, この絡み合いが架橋時に網目中にトラッ プされる (trapped entanglement). trapped entanglement は, 溶液, 溶融体中の絡み合いと異なり, 化学架橋点に よるトポロジー的制限のために永久に緩和できないため， 弾性的に有効な架橋点として平衡状態においても網目の 弾性に寄与する. ${ }^{18) ~}{ }^{20)}$ したがってこの場合, 絡み合い点 を化学架橋点と同等に取り扱った場合の架橋点間の網目 鎖の長さ $\left(N^{\prime}\right)$ を $\lambda_{\text {max }}$ の計算に用いなければならない. $N^{\prime}$ は高分子溶融体に打け方絡み合い点間距離に相当する セグメント数 $\left(N_{e}\right)$ に等しいと考えてよいので，その典型 的な值 $20 \sim 40$ を用いると $\lambda_{\text {max }}=4 \sim 6$ となる. バルク 状態で架橋する限り， $N_{e}$ で決まる $\lambda_{\text {max }}$ を大きく上回る ことはできず，通常のゴム架橋体の $\lambda_{\text {max }}$ が 10 を大きく 超えることが少ないのはこの制限による.

$\lambda_{\text {max }}$ を向上させるには， $N_{e}$ を大きくする，すなわち絡 み合いの数を減らすことが必要であり, 低濃度溶液中で の架橋がこの条件を満たす簡便な方法である，溶液中で は $N_{e}$ は濃度のほぼ-1 乗に比例し ${ }^{18),}{ }^{19}$ 濃度の減少とと もに增加する。脱膨潤ゲルは，低濃度溶液から作製され たゲルから溶媒を完全除去することによって得られる． 脱膨潤時にゲルは溶媒を失い体積減少を起こすため,こ れに伴い網目鎖のコンフォメーションが密になり (supercoil)，網目鎖の両末端間距離が減少すると考えられる. 網目鎖の両末端間距離は, 脱膨潤時のアフィン変位を仮 定すれば濃度の $1 / 3$ 乗に比例して減少する。従って, 低 濃度溶液から作製された脱膨潤ゲルは, 網目中の絡み合 
い数が少なく，未変形時の網目鎖の両末端間距離が短い という網目構造のトポロジー的特徴を有し，両者ともに 伸長性の向上に有利に働く，上述の議論に従えば，ポリ マーの体積分率 $\phi$ の溶液から作製された脱膨潤ゲルの $\lambda_{\text {max }}$ は

$$
\lambda_{\max }=\frac{b N_{e}(\phi)}{b N_{e}(\phi)^{1 / 2}(\phi)^{1 / 3}}=N_{e}(1)^{1 / 2} \phi^{-5 / 6}
$$

式 (1) によれば, 数\%のポリマー濃度の溶液から調製 した脱膨潤ゲルの $\lambda_{\text {max }}$ は 100 に達する。

\section{$3 \cdot 2$ 脱膨潤 PDMS ゲルの超高伸長性 $\left.\left.{ }^{13)} \sim 16\right), 21\right)$}

図 4 に $\phi=0.1$ で作製した脱膨潤 PDMS ゲル，および バルク架橋 PDMS ゲル $(\phi=1)$ の応力 $\left(\sigma_{e}\right)$ 一伸び $(\lambda)$ 曲 線を示す，応力は工学応力であり，図中の応力は各試料 のヤング率で規格化されている。罒から明らかなように， バルク架橋ゲルの $\lambda_{\text {max }}$ が約 2 であるのに対し脱膨潤ゲル の $\lambda_{\text {max }}$ は 31 に達しており，脱膨潤法が $\lambda_{\text {max }}$ の向上に効 果的であることがわかる．脱膨潤ゲルは大変形後に応力 を解放すると変形前のサイズに完全に回復するため，こ の高伸長性は塑性によるものではない。この脱膨潤 PDMS ゲルの $\lambda_{\max }=31$ は，過去のエラストマーの $\lambda_{\max }$ の報告值としては最高值と考えられている. ${ }^{16)}$ 四中に古典 ゴム弾性論の予測 $\left(\sigma_{e} / E=\left(\lambda-\lambda^{-2}\right) / 3\right)$ を示す：古典ゴム 弾性論は絡み合い効果などの分子間相互作用を無視した random-coil から成る網目に対する予測であるが，脱膨 潤ゲルの応力の伸び依存性はこの予測に比べると著しく 弱いことがわかる。この弱い応力の伸び依存性は, 高伸 長性を示す脱膨潤ゲルに特徴的なものであり，脱膨潤時 に形成される網目鎖の特異なコンフォメーション supercoil に起因するものと考えられる。この応力の伸び依存 性の解析は次項で述べる。

\section{$3 \cdot 3$ 脱膨潤ゲルの応力の伸び依存性 ${ }^{21), 22)}$}

大変形下の一本鎖の応力の伸び依存性の問題は, Pincus による理論的取り扱いがある.10), 14)，23)，24) この理 論によれば, 大変形下のフラクタル次元 $\mathrm{D}$ の一本鎖の $\sigma_{e}$ の $\lambda$ 依存性は

$$
\sigma_{e} \sim \lambda^{1 /(D-1)}
$$

である，我々は，ゲルの応力は各網目鎖に働く応力の合

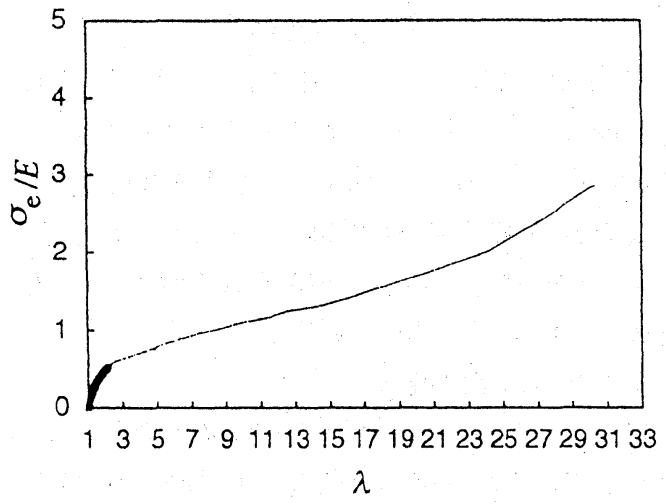

図 4 脱膨潤 PDMS ゲル (実線) とバルク架橋 PDMS ゲル (太線) の規格化応力一伸び曲線
力に相当すると考え, 式 (2) による実験データの解析を 試みた。まず， $D$ が既知である random-coil $(D=2)$ か ら成るゲルの $\sigma_{e}$ の $\lambda$ 依存性を調べ, 式 (2) の実験的検証 を行いその妥当性を確認した. ${ }^{21)}$ 図 5 に $\phi=0.15, \phi=$ 0.10 で作製された脱膨潤 PDMS ゲルの規格化応力と $\lambda$ $\lambda^{-2}$ の両対数プロットを示す. 応力は各試料の初期せん 断弾性率 $G(=E / 3)$ で規格化されている. $\phi=0.15, \phi=$ 0.10 のプロットは良く一致し濃度依存性が見られないこ とから，図 5 に見られる応力の伸び依存性は super-coil の網目鎖から成る脱膨潤ゲルの典型的なものであると考 えられる。 $\sigma_{e}$ の入依存性は次の 3 領域に分けられる： $\sigma_{e}$ $\sim\left(\lambda-\lambda^{-2}\right)(1<\lambda<1.6)$ (領域 I ) ; $\sigma_{e} \sim \lambda^{0.46}(1.6<\lambda<$ 16) (領域 II ) ; $\sigma_{e} \sim \lambda^{1.0}(16<\lambda<31)$ (領域 III ) 領域 I は, 古典ゴム弾性論の予測に従う小さな変形領域である. 領域 II およびIIIでは，非常に広い $\lambda$ の範囲で $\sigma_{e}$ の $\lambda$ 依 存性が一定のべキ乗則に従うことは興味深い. 領域 II を super-coil を解きほぐす過程とみなし式 (2) を用いると $D$ $=3.2$ となり, super-coil が random-coil $(D=2)$ よりも空 間的に密なコンフォメーションであることが示唆される. また，領域且は式 (2)の $D=2$ の場合に相当し, supercoil が解きほぐされた後は random-coil 型の力学応答に なっていることがわかる．領域 II から IIIへの $\sigma_{e}$ の入依存 性のクロスオーバー挙動は文献 12 で予測されているが, クロスオーバーが起こる $\lambda$ 值 $(\lambda=16)$ はこの系に対する 理論の予測 $(\lambda=8)$ よりもかなり大きい.

著しい高伸長性, 特異な応力の伸び依存性だけでなく， 脱膨潤ゲルは低温結晶化挙動にも異常が見られることが 報告されている. ${ }^{25)}$ 脱膨潤ゲルはその網目構造のユニーク なトポロジー的特徴のために，ここで紹介した以外の物 性においても特異性を示すと考えられ, 収縮した網目鎖 のコンフォメーション自体のキャラクタリゼーションも 含めて, 今後の研究が期待される.

\section{4 変形下および流れ場中の高分子ゲルの膨潤}

高分子ゲルは高分子網目が溶媒で膨潤したものであり， その力学特性は主に高分子網目の物性によって規定され ている。もちろん，弾性率などには濃度依存性が見られ るが, これらの場合には溶媒の存在がゲルの力学挙動に

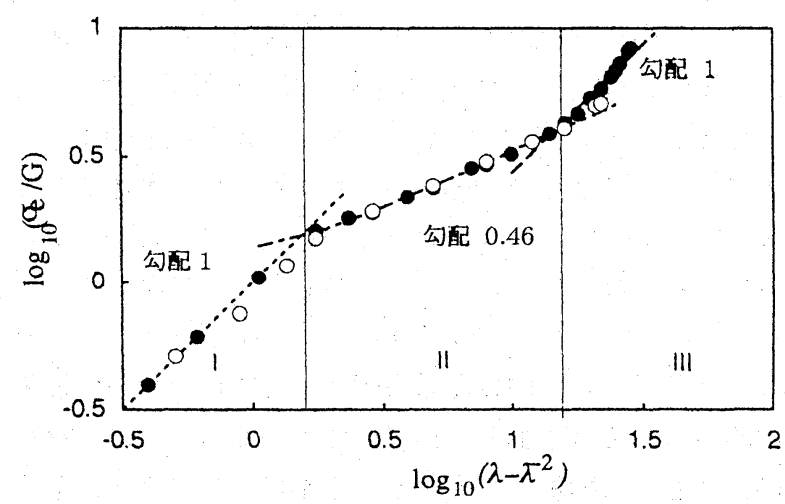

図 5 脱膨潤 PDMS ゲル（黒丸： $\phi=0.1$; 白丸： $\phi=$ 0.15）の規格化応力 vs. $\lambda-\lambda^{-2}$ の両対数プロット 
本質的な影響を与えていることはない. 一方, 溶媒の存 在が力学物性に本質的な影響を与える場合がある。これ は高分子ゲルの力学物性を溶媒中で調べる場合に見られ， 変形（あるいは力）の印加により高分子網目と溶媒との 間の熱力学的な相互作用の強さが変化するために起こる. 高分子ゲルでこのような現象が見られるためには, ゲル 中で力を支えるストランドが単一（あるいは, 数本程度 なら高分子鎖の集合体でもよいかもしれないが）の高分 子鎖であることが必要であり, ストランドが多数の分子 の集合体である場合（例えば，医用分野で使われている コラーゲンゲルなど）では現れないと考えられている．以 下では外部溶媒の存在が高分子ゲルの力学物性にどのよ うな影響を与えるかに幾つかの例を示しながら解説する.

\section{$4 \cdot 1$ 変形下にあるゲルの膨潤 ${ }^{26)} \sim 29$ )}

溶媒中にある高分子ゲルに変形を加えると, 系の自由 エネルギー $(F)$ は，

$$
F=F_{0}+\int \boldsymbol{f} \cdot d \boldsymbol{r}
$$

となる.ここで, $F_{0}$ は未変形状態のゲルの自由エネルギ 一, $\boldsymbol{f}$ および $d \boldsymbol{r}$ は各々ゲルにかかっている力と微小変位 である. 右辺の第 2 項は系に加えられた仕事に対応する. 変形の印加でゲルの自由エネルギーが変化すると, ゲル は体積 $(V)$, 正確にはゲル中にある溶媒分子の数 $\left(N_{s}\right)$, を変化させて変形下での安定状態に移る，この変形下で のゲルの平衡状態は, $F$ を $V$ の関数とみなすと $\partial F / \partial V=$ 0 で決まることになる。 ここで, $-\partial F / \partial V$ は浸透圧（膨潤 圧）に対応する物理量である. 簡単のため, 以下では変 形を一軸伸長変形とする. 変形下でのゲルの膨潤の指標 となる平衡ポアソン比 $\left(\mu_{\infty}\right)$ は, $\varepsilon_{/ /}$と $\varepsilon_{\perp}$ (を各々伸長方 向およびそれに垂直な方向のひずみとすると,

$$
\mu_{\infty}=-\frac{\varepsilon_{\perp}}{\varepsilon_{/ /}}
$$

で与えられ, 変形印加後のゲルの体積 $V$ は変形前の体積 を $V_{0}$ とすると,

$$
V=V_{0}\left(1+\varepsilon_{/ /}+2 \varepsilon_{\perp}\right)
$$

となる. 式 (4) は, 通常の物質定数としてのポアソン比 $\left(\mu_{0}\right)$ と全く同じ定義式であるが, $\varepsilon_{/ /}$を印加した後の $\varepsilon_{\perp}$ は平衡条件, すなわち $\partial F / \partial V=0$ から決まることにな

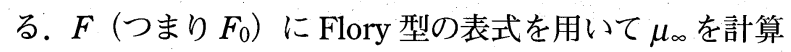
すると， $\mu_{\infty}=1 / 6$ となることが示される. ${ }^{26)}$ もちろん， この值は用いる自由エネルギーの表式に依存する，例え ば，別の自由エネルギーの表式を用いた計算では， $1 / 4$ となることが示されている. ${ }^{29)}$ しかしながら, どのような 表式を用いても $\mu_{\infty}$ の值は $1 / 2$ よりもかなり小さくなる ようである.ゴムの $\mu_{0}$ の值が $1 / 2$ に近いことはよく知ら れている. 高分子ゲルでも，物質定数としてのポアソン 比 $\mu_{0}$ は $1 / 2$ に近いことが報告されている. ${ }^{30), 31)}$ このこと は, 高分子ゲルに伸長変形を印加した場合のゲルの体積 は印加直後では印加前の体積と変わらないものの, 時間 の経過と共に増加（膨潤）し，やがて一定になることを 示している. この膨潤の駆動力は, 先に述べたように変 形印加によるゲルの自由エネルギー変化であり, これに
よりゲルの外部にある溶媒分子が溶媒相とゲル相の界面 を通ってゲル内に移動しゲル中の高分子濃度（ゲルの膨 潤度）が変化する. 変形下での新しい平衡状態が実現さ れるまでこの膨潤度の変化は続く。また, この変化は溶 媒分子の移動を伴うため, 変化に要する時間（緩和時間） がゲルの大きさに依存する，大きいゲルほど緩和に要す る時間が長くなる。実際に, 溶媒中で未変形状態で平衡 状態にある高分子ゲルをある長さまで伸長しその長さを 保持した場合，ゲルはゆっくりと膨潤することが実験に より確かめられている. 実験で求められた $\mu_{\infty}$ の值は $1 / 6$ 〜 1/3 の範囲にあるようである. ${ }^{28), 32)}$

\section{$4 \cdot 2$ ゲルの膨潤のキネティクス ${ }^{26), 27)}$}

ゲルの膨潤のキネティクスを定量的に取り扱うために は, ゲル中の微小体積要素に関する構成方程式や運動方 程式が必要となる。以下では, 自由膨潤だけでなく後に 述べる応力緩和なども取り扱えるよう外部から力がかか っている状態でのゲルの膨潤を考える．簡単のため，微 小変形の場合のみを取り扱う。この場合, 膨潤過程での ゲル中の体積要素にかかっている全応力 $\left(s_{\mathrm{tot}}\right)$ は,

$$
\begin{aligned}
& \boldsymbol{s}_{t o t}=\boldsymbol{s}_{o s}+\boldsymbol{s} \\
& \text { であり, 全ひずみ }\left(u_{t o t}\right) \text { は } \\
& \boldsymbol{u}_{t o t}=\boldsymbol{u}_{o s}+\boldsymbol{u}
\end{aligned}
$$

である.ここで, $\boldsymbol{s}_{o s}$ と $\boldsymbol{s}$ は各々, 膨潤応力と外力からの 応力への寄与（外部応力）である.この要素にかかって いる膨潤圧は-Trs $s_{o s} / 3$ で与えられる。また， $\boldsymbol{u}_{o s}$ と $\boldsymbol{u}$ は それぞれ膨潤ひずみと外部ひずみであり， $\boldsymbol{u}_{\infty}$ は $\boldsymbol{u}_{o s}$ の平 衡値である. 膨潤応力 $s_{o s}$ は，

$$
\boldsymbol{s}_{o s}=2 G\left(\boldsymbol{u}_{o s}-\frac{1}{3}\left(\operatorname{Tr} \boldsymbol{u}_{o s}\right) \boldsymbol{I}\right)+K_{o s} \operatorname{Tr}\left(\boldsymbol{u}_{o s}-\boldsymbol{u}_{x}\right) \boldsymbol{I}
$$

で与えられ, $\boldsymbol{s}$ は $\mu_{0}=1 / 2$ のときは

$$
\boldsymbol{s}=2 G \boldsymbol{u}-p \boldsymbol{I}
$$

$\mu_{0} \neq 1 / 2$ のときは，

$$
\boldsymbol{s}=2 G \boldsymbol{u}+\left(K-\frac{2}{3} G\right)(T r u) \boldsymbol{I}
$$

で与えられる，ここで， $G$ は剛性率， $K$ は体積弾性率で ある. また， $p$ は境界条件から決まる定数であり， $K_{o s}$ は 浸透圧（膨潤圧）に関係した体積弾性率である。要素の 体積の時間 $(t)$ 発展は慣性項を無視すると以下のように なる。

$$
f \frac{\partial \boldsymbol{r}_{o s}}{\partial t}=\operatorname{div} \boldsymbol{s}_{o s}
$$

ここで $\boldsymbol{r}_{o s}$ は膨潤変形に対する変形べクトルであり,$f$ は 高分子網目と溶媒との間の摩擦係数である.

任意の形状のゲルの変形下での膨潤挙動は適当な条件 下で式 (10) を解けば計算で推定できることになる。しか しながら, 式 (10) の解析解が得られるのは, 球や円筒な ど単純な形状のゲルに限られる.

\section{$4 \cdot 3$ ゲルの応力緩和 ${ }^{26), 27)}$}

溶媒中にある高分子ゲルに変形を加えた後, その状態 を保持していると, 応力が時間と共に減少する応力緩和 が観測される．応力緩和はゲルに空気中で変形を加えた 場合にももちろん見られるが, 溶某中での実験では先に 
述べた変形下でのゲルの膨潤に起因する応力緩和が見ら れる。ここでは，変形下でのゲルの膨潤による応力緩和 について述べる.

一軸伸長変形下での伸長応力 (外部応力; $\sigma$ は，加えた ひずみ（外部ひずみ； $\varepsilon_{/ /}$）が小さいときには， $\mu$ をポア ソン比とすると,

$$
\sigma=2(1+\mu) G \varepsilon_{/ /}
$$

となる. 先に述べたように, 物質定数としてのポアソン 比は高分子ゲルの場合もゴムと同様に $1 / 2$ に近い值を示 すので, 変形印加直後では, $\mu=\mu_{0} \neq 1 / 2$ である. $\mu_{0}=$ $1 / 2$ とすると変形直後の応力（すなわち, 外部応力の初 期の值； $\sigma_{0} ）$ は $\sigma_{0}=3 G \varepsilon / /$ となる. 一方, 十分時間が経 過し変形下で平衡状態にあるゲルのポアソン比は $\mu_{\infty}$ であ り, 先に示した平衡ポアソン比の值, $\mu_{\infty}=1 / 6$ を用いる と, 十分時間が経過したときの外部応力 (平衡応力; $\sigma_{\infty}$ ) は $\sigma_{\infty}=(7 / 3) G \varepsilon_{/ /}$となる. つまり, 平衡応力 $\left(\sigma_{\infty}\right)$ は初期 応力 $\left(\sigma_{0}\right)$ の $7 / 9$ となり, 応力が時間と共に減少すること がわかる．この応力の時間変化の詳細はここでは述べない が，これを定性的に理解するためには，外部応力と外部 ひずみに関する以下の対応関係に着目すればよい.

$$
\boldsymbol{\sigma} \leftrightarrow \mathbf{s}, \varepsilon \leftrightarrow \mathbf{u}
$$

これらの関係の中の左側の量はゲル全体に関する量 $(\sigma$; 応力テンソル： $\varepsilon$; ひずみテンソル) であり, 右側 の量は先に述べたようにゲル中の微小要素に関する量で ある.ゲル全体に関する全応力 $\left(\sigma_{t o t}\right)$, 全ひずみ $\left(\varepsilon_{t o t}\right)$, 膨潤応力 $\left(\boldsymbol{\sigma}_{o s}\right)$ および膨潤ひずみ $\left(\boldsymbol{\varepsilon}_{o s}\right)$ についても同様の 対応関係が存在する. 応力緩和の実験では, 伸長方向の 全ひずみ $\left(\boldsymbol{\varepsilon}_{t o t}\right)$ を一定に保つ。例えば, 非圧縮性のゲル では, ゲル全体にかかる外部応力（テンソル） $\boldsymbol{\sigma}$ は, $\boldsymbol{s}$ との類似性（式 (9a)）からわかるように, 外部ひずみ $\boldsymbol{\varepsilon}\left(=\left(\boldsymbol{\varepsilon}_{t o t}-\boldsymbol{\varepsilon}_{o s}\right)\right)$ の関数となることがわかるであろう. 一定のひずみを加えた後, その状態にゲルを保持してい ると, $\boldsymbol{\varepsilon}_{t o t}$ は時間が経過しても変化しないが伸長方向の 膨潤ひずみ $\varepsilon_{o s}$ は膨潤により時間と共に変化する．この $\boldsymbol{\varepsilon}_{o s}$ の時間変化が応力緩和として現れるのである. ポリ アクリルアミドゲルでこのような応力緩和が見られるこ とが知られている。

\section{$4 \cdot 4$ 流れ場中にある高分子ゲルの膨潤 ${ }^{33}$}

ゲルを膜として用いる場合のように, ゲル中の溶媒が 流動するとゲルは膨潤する.この場合, ゲルの体積（膨 潤度）の時間変化は流れ場中の溶媒圧分布の時間変化で 決まることになる．このため，膨潤度が一定になるのに 要する時間とゲル膜を透過する溶媒流量が定常になるの に要する時間とはほぼ等しくなる。また，定常状態での 膨潤度は圧力差と浸透圧に関する体積弾性率 $\left(K_{o s}\right)$ だ で決まり，摩擦係数には依存しない．これらのことは以 下の簡単なモデルで説明することができる.

高分子網目と溶媒は非圧縮性と仮定し，連続体近似を 用いる. 溶媒の流れ方向を $\mathrm{x}$ 方向とするとゲル中の微小 要素に対し,

$$
\frac{\partial T r \boldsymbol{u}_{o s}}{\partial t}+\frac{\partial \dot{v}}{\partial x}=0
$$

という保存則が成り立つ。ここで， $\boldsymbol{u}_{o s}$ は先と同じ膨潤ひ ずみテンソルであり， $v$ は溶媒の速さである。ゲル中の 溶媒の流れをDarcy 流れとみなすと以下の関係が得ら れる。

$$
\frac{\partial p}{\partial x}=-f v
$$

ここで, $p$ は溶媒の圧力, $f$ は先に定義した高分子網目と 溶媒との間の摩擦係数である。この係数 $f$ は溶媒の粘度 $(\eta)$ と透過係数 (Darcy 定数； $P$ ) を用いると $f=\eta / P$ とな ることが知られている．高分子網目（ゲル）は溶媒の圧 力により膨潤する. 膨潤が等方的に起こると仮定すると, 高分子網目（ゲル）の膨潤の程度は

$$
T r u_{o s}=\frac{p}{K_{o s}}
$$

で決まると考えられる. 式 $(12) \sim(14)$ より, $p=p(x, t)$ の時間発展は,

$$
\frac{\partial p}{\partial t}=D_{f} \frac{\partial^{2} p}{\partial x^{2}}
$$

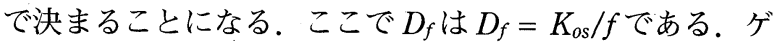
ル全体の膨潤度（体積）やゲル表面から流出する溶媒の 量などは $p(x, t)$ から計算することができる. ポリビニル アルコールゲルは溶媒の流れにより膨潤する。その詳細 が上のモデルに基づき解析されている。

\section{参 考 文 献}

1) 大柳 康, 粷谷信三, “熱可塑性エラストマーの新展開” （1993）工業調查会.

2）池田裕子, 粷谷信三, 日本ゴム協会誌, 62, 357 (1989).

3 ) 㭵谷信三, 材料, 39, 1173 (1990)

4) A. Y. Coran, R. Patel, Rubber Chem. Technol., 53, 141 (1980).

5 ）菊池 裕, 岡田哲雄, 井上 隆, 日本ゴム協会誌, 64, 540 (1991).

6) Y. Kikuchi, T. Fukui, T. Okada and T. Inoue, Polym. Eng. Sci., 31, 1029 (1991).

7 ) S. Kawabata, S. Kitawaki, H. Arisawa, Y. Yamashita and X. Guo, J. Appl. Polym. Sci. : Appl. Polym. Symp., 50, 245 (1992).

8 ）小谷悌三, 川島正昭, 鈴木 進, 日ゴム協誌， 12, 1030 (1969).

9) W. W. Graessley, Adv. Polym. Sci., 16, 1 (1974).

10) P.-G. de Gennes, "Scaling Concepts in Polymer Physics" (1979) Cornell Univ. Press.

11) G. Heinrich, E. Straube and G. Helmis, Adv, Polym. Sci., 85, 33 (1988).

12) S. P. Obukhov, M. Rubinstein and R. H. Colby, Macromolecules, 27, 3191 (1994).

13）浦山健治，池田裕子，粷谷信三，日ゴム協誌， $68 ， 815$ (1995).

14) K. Urayama and S. Kohjiya, Polymer, 38, 955 (1997). 
15) S. Kohjiya, K. Urayama and Y. Ikeda, Kaut. Gummi. Kunst., 50, 868 (1997).

16) 浦山健治, 高分子, 47, 572 (1998).

17) W. Kuhn, J. Polym. Sci., 1, 380 (1946).

18) K. Urayama and S. Kohjiya, J. Chem. Phys., 104, 3352 (1996).

19) K. Urayama, T. Kawamura and S. Kohjiya, J. Chem. Phys., 105, 4833 (1996).

20) T. Kawamura, K. Urayama and S. Kohjiya, Nihon Reoroji Gakkaishi, 25, 195 (1997).

21) K. Urayama and S. Kohjiya, Eur. Phys. J. B, 2, 75 (1998).

22) K. Urayama, K. Yokoyama and S. Kohjiya, "The Wiley Polymer Networks Group Review Series”, Vol. 2, B. T. Stokke \& A. Elgsaeter, Eds., p.485 (1999) John Wiley \& Sons.

23) P. Pincus, Macromolecules, 9, 386 (1976).

24) S. J. Daoudi, J. Phys. France, 38, 1301 (1977).

25) K. Urayama, K. Yokoyama and S. Kohjiya, Polymer, 41, 3273
(2000).

26) T. Takigawa, K. Urayama, Y. Morino and T. Masuda, Polym. J., 25, 929 (1993)

27) T. Takigawa, K. Urayama and T. Masuda, Polymer Gels \& Networks, 2, 59 (1994).

28) T. Takigawa, Y. Morino, K. Urayama and T. Masuda, Polym. J., 28, 1012 (1996).

29）例えば, 土井正男, “大学院物性物理 3”(1996) 講談社.

30) T. Takigawa, Y. Morino, K. Urayama and T. Masuda, Polymer Gels \& Networks, 4, 1 (1996).

31) K. Urayama, T. Takigawa and T. Masuda, Macromolecules, 26, 3092 (1993).

32) E. Geissler, A. M. Hecht and F. Horkay, M. Zrinyi, Macromolecules, 21, 2594 (1988).

33) T. Takigawa, K. Uchida, K. Takahashi and T. Masuda, J. Chem. Phys., 101, 2295 (1999). 